DOI: https://doi.org/10.34069/AI/2022.49.01.12 How to Cite:

Asieieva, Y., Orlenko, I., Borinshteyn, E., Atamaniuk, Z., \& Dobrolyubska, Y. (2022). Intuition as a philosophical reflection at the time of COVID-19 pandemic. Amazonia Investiga, 11(49), 108-116. https://doi.org/10.34069/AI/2022.49.01.12

\title{
Intuition as a philosophical reflection at the time of COVID-19 pandemic
}

\section{Інтуїція як філософська рефлексія в період пандемії COVID-19}

Received: November 8, 2021
Accepted: December 26, 2021

Written by:

Yuliia Asieieva ${ }^{43}$

https://orcid.org/0000-0003-3086-3993

Irina Orlenko ${ }^{44}$

https://orcid.org/0000-0002-6322-0217

Evgenij Borinshteyn ${ }^{45}$

https://orcid.org/0000-0002-0323-4457

Zoia Atamaniuk ${ }^{46}$

https://orcid.org/0000-0001-7299-409X

Yuliya Dobrolyubska ${ }^{47}$

https://orcid.org/0000-0002-3564-854X

\begin{abstract}
By January 2021, the number of Internet users amounted to 4.7 billion, while the social media audience hit the 4.2 billion mark. Two-thirds of the world's population use mobile phones daily. The average Internet user spends $42 \%$ of his time in the global network. These figures prove convincingly that the Internet has become an integral part of human life. However, man's using the Internet involves increasingly the risk of cybercrime perpetrated against the user. The purpose of the research is to assess the potential of Big Data technologies to combat cyber fraud as a form of cybercrime. The study used the statistical data provided by the Prosecutor General's Office of the Russian Federation and the publications in scientific journals. The methodological basis of the research is represented by a combination of general scientific and special scientific methods, with analysis, statistical method and systemic approach being the major tools. It was found in the course of the research that fraud constitutes the majority of crimes on the Internet. To counteract it, mobile operators and banks use
\end{abstract}

\begin{abstract}
Анотація
Автори розкривають важливість питання про безумовне прийняття певних обмежень в соціальному житті в період пандемії COVID19 , зробивши основний акцент на вивченні інтуїтивних процесів і філософської рефлексії про формування поведінкових реакцій в соціумі, що і $\epsilon$ метою даної статті. Проаналізувавши існуючі концептуальні підходи, автори відзначають, що в даний час існує декілька теорій інтуїції, які пояснюють iii сутність і зміст - такі як гносеологічна, містична, і як первинна сверхраціональна ступінь осягнення «цілісного буття», що несе в собі ідею освоєння світу. Вчені стверджують, що згідно гносеологічної логіці, ми мислимо від абстрактної інформації про COVID-19 до конкретних випадків, пов'язуючи їх воєдино, тим самим змінюючи звичні форми поведінки на більш асоціальні. $\quad$ COVID-19 викликав універсальний психосоциальний вплив, що викликав масову тривогу, економічний тягар і фінансові втрати - які карантин тільки посилив. I подальше ставлення до ситуації
\end{abstract}

\footnotetext{
${ }^{43}$ Doctor of Psychological Sciences, senior lecturer at the Department of Psychiatry, Medical and Special Psychology of the State Institution «South Ukrainian National Pedagogical University named after K.D. Ushynsky», Odessa, Ukraine.

${ }^{44} \mathrm{Head}$ of Odessa regional resource center for inclusive education support of Communal Institution of higher education "Odesa Academy of Continuing Education of Odesa regional council" Odessa, Ukraine.

${ }^{45}$ Doctor of Philosophical Sciences, Professor, Head of the Department of philosophy, sociology and management of social and cultural activities, "South Ukrainian National Pedagogical University named after K. D. Ushynsky", Odessa, Ukraine.

${ }^{46}$ Doctor of sciences in Philosophy, Associate at the Department of philosophy, sociology and management of socio-cultural activity, State institution «South Ukrainian National Pedagogical University named after K.D. Ushynsky», Odessa, Ukraine.

${ }^{47}$ Doctor of sciences in Philosophy, Professor, Head of the Department of World History and Methodology of Science, State Institution «South Ukrainian National Pedagogical University named after K.D. Ushynsky», Odessa, Ukraine.
} 


\section{AMAZONDA
Drvestiga}

anti-fraud techniques based on Big Data analysis. The paper provides an overview of services and programmes based on artificial intelligence and Big Data technologies, aimed at detecting and preventing telephone and internet fraud, used by law enforcement agencies in various countries. The paper concludes that Big Data has changed the vector of law enforcement activity from reactive to proactive.

Keywords: information, Big Data, cybercrime, cyber fraud, anti-fraud.

пандемії залежить від того наскільки спрацьовує механізм проникливості, чуттєвопредметної діяльності соціальної особистості, яка спрямована на зміну навколишнього соціального середовища i себе. Грунтуючись на вивченні механізмів формування інтуїтивної поведінки, слід готувати грунт до формування неусвідомленого засвоєння переживання складних ситуацій не в згуртуванні з групою, а індивідуально, базуючись на умовах підпорядкування авторитету в складних ситуаціях. Надання чітких інструкцій, створення нових алгоритмів реагування дозволить сформувати правильні знання про поведінку в ситуації пандемії.

Ключові слова: інтуїція, філософська рефлексія, проникливість, пандемія, дезадаптація, COVID-19.

\section{Introduction}

The beginning of the 21st century is marked by events that have irreversibly changed every person's life. COVID-19 that had burst into measured and virtually socially foreseen life, outlined the boundaries of the future unacceptable, impossible and certainly unpredictable. It is quite surprising that at the threshold of digital revolution we faced an uncontrollable and almost unpredictable state of our society. The situational awareness based on social foresight and social perspicacity will allow society to somewhat reduce the level of tension and panic - and in turn will help to avoid maladaptation of society at all structural levels.

And this situation of maladaptation is increasing due to the spread of coronavirus infection, which affects the emotional state of people as a result of a lack or excess of information (Leshchyna, Asieieva, Vasylieva, Strelnikova, \& Kovalska, 2021). Any information we possess affects our cognitive intuition, that is, it becomes the basic foundation of our perspicacity. And the further attitude towards the situation of the pandemic depends on how functions the mechanism of perspicacity and sensory-substantive activity of a social personality, which is focused on changing the surrounding social environment and oneself.

The emergence of previously unknown form of the COVID-19 virus has focused the world's attention on itself, thereby causing shock and perception of the situation as a crisis. In such cases the person interprets the event within the framework of his own experience or recalls similar situations from the experiences of others.
According to epistemological logic, we think from abstract information about COVID-19 to specific cases, binding them together and, thereby changing the usual forms of behavior to more asocial. COVID-19 has caused a universal psychological effect, triggering the mass anxiety, economic burden and financial losses - and the lockdown has only strengthened it. The deterioration in the quality of life, loss of productivity and growing social inequalities will have long-term consequences for the world society development. The sense of necessity of making a quick decision interferes with the logical comprehension of the crisis situation and causes panic. Thus, a person in a state of panic cannot foresee the reality, his consciousness, sociocultural and individual psychological properties of the personality are blocked. Under the influence of frustrating situations, the mind begins to «work» fluctuationally, that leads to inhibition of a person's ability to fully realize his actions. Thus, the logistics of actions are lost, intuition as a way of discovering the world (inherent solely to humans) ceases to function normally. This leads to deviation of the hypothetical-deductive nature of cognition, thereby contradicting one of the basic principles of mechanics formulated by Isaac Newton. (Newton, 1989; Kravchenko, 2002).

\section{Theoretical Framework or Literature Review}

The scientific world community is considering the issue of predicting the consequences of open border crossing under lockdown conditions. For example, scientists Subhra Rajat Balabantaray, 
Archisman Mohapatra (2020) emphasize that in the context of the interconnected and interdependent global economy, governments failed to foresee the importance of promptly imposing restrictions on international travel. In early 2020, international trade and travel continued mainly as usual, leading to the rapid spread of the virus. Countries whose governments have been more active coped with the pandemic without absolute isolation. They either took a strong position against lockdown (e.g. Sweden, Germany and in the early days the UK) or did so after strict control measures (e.g. New Zealand, Australia, Croatia and Greece).

However, Subhra Rajat Balabantaray and Archisman Mohapatra (2020) claim that the uncertainty about the unfolding pandemic and decisions about the lockdown implementation were usually made without strategies of realization, exit and mitigation. From their point of view, low- and middle-income countries (LMICs), where the lockdown had led to significant socio-economic problems, should have carefully weighed this decision. All of their socio-economic systems are chronically underresourced and face problems that cannot be quickly remedied. This has aggravated problems for people, countries and the world as a whole. People have lost their jobs and livelihoods. Appeared an increase in reports of stress, anxiety, depression, suicide, and domestic violence. Some countries implemented a lockdown in very short time periods (for example, India and Italy), which absolutely heightened the panic-stress moods.

Subsequent declines in quality of life and productivity, rising social inequalities and feelings of sociocultural injustice are likely to have long-term implications for the further development of society. At the individual level, loss of livelihood can lead to functional impairment and mental health problems (Balabantaray \& Mohapatra, 2020). And to the socio-cultural maladaptation not only of individual society members, but also of society, the country and the institution of the state as a whole.

Tina Lindhard (2020) shifts the focus of our attention during a pandemic from the external to the internal state, and from the overusing of logical thinking, related to the brain, to the sensory mind, connected to the heart. This epistemological method of cognition is based on intuition. However, in order to find solutions to the many problems we face today, far more people need to learn to penetrate into their hearts.
The author scientifically proves that the importance of sensory intuition is crucial for solving urgent problems associated with COVID-19 (Lindhard, 2020 p. 181-194).

In this situation, from our point of view, perspicacity is of great importance not only as a quality of a person, expressed in the ability to notice, feel, anticipate and predict the intentions, actions and deeds of other people, the development of processes and phenomena in real conditions (Nakonechnaya, 2016), but also, from a philosophical point of view, «direct guessing (we would even say: «prediction», «forecasting» - E. B., I.O.) or understanding of one or another logical connection» (Ilyichev, Fedoseev, Kovalev, \& Panov, (Ed.) 1983, p. 368).

It seems important to us that the modern scientist Singh Siddhart (2020) views perspicacity as often intuitive decisions. So, in his study, he describes situations during a pandemic, where the insecurity of any person is a threat to himself. In his opinion, the COVID-19 pandemic has changed the definition of economic principles. Situations such as panic buying and hoarding can be explained through the perception of the threat. During a pandemic, the «pure rational» person is replaced by the «emotionally rational» person. During pandemics, people often make intuitive decisions. The author describes solutions based on behavioral research. His findings on the importance of behavioral changes and the shaping of new behavioral strategies can help reduce the spread of the COVID-19 virus (Siddharth, 2020).

At the same time, for us seems to be important the Kantian understanding of intuition as a way by which cognition is directly correlated with one or another object; and as that by means of which we take an object for granted (Kant, 1994, p. 59). In this case, we come to a philosophical and logical understanding of intuition as the ability to «comprehend the truth through its direct perception without justification by means of proof» (Ilyichev et al, 1983, p. 216), which is significant when analyzing the consequences of a pandemic.

\section{Methodology}

Taking into account the serious consequences of non-compliance with quarantine measures due to lack of perspicacity and the lack of elementary forecasting based on intuition among most of the world's population, it is extremely important to understand why people resist measures compliance. Since the early days of the virus 


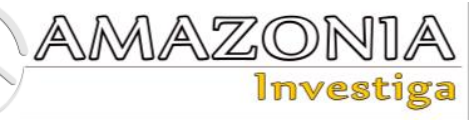

outbreak, misinformation about COVID-19 has spread widely on social networks, radio and the media. In order to understand how people often react to information about COVID-19 and whether they are ready to change their behavioral habits, we investigate: the effect of panic on intuition - whether it predicts beliefs that the COVID-19 pandemic is a hoax; and perspicacity as predicting that compliance with quarantine measures (e.g. social distancing and more frequent hand washing or wearing a medical mask in public areas) is a real situation in society. Our research aims to explore the opportunities of intuitive perspicacity to overcome the false conviction associated with panic in modern society, and to develop a system of human behavior, social groups and society as a whole, that is aimed at overcoming panic in the context of a pandemic.

The term «intuition» and the philosophical teachings about intuition for the first time originated in ancient Indian and ancient Greek philosophy.

Even the ancient Greek philosopher Plotinus believed that intuition is a divine way of instantly knowing something.

The word «intuition» was included into European philosophy back in the 13th century as an analogue of the ancient Greek term, which meant the knowledge of an object not in parts, but as a whole.

Plato, Descartes, Locke, Spinoza were of the opinion that intuition is direct knowledge that does not need proof and is perceived as reliable. At the same time, Rene Descartes reduced all the acts of thinking that allow us to gain new knowledge without fear of error, to two intuition and deduction.

However, Immanuel Kant denied Cartesian intellectual intuition and emphasized sensory intuition and pure intuition of space and time.

In the process of cognition, as I. Kant suggested, there are involved two components: sensory experience and rational thinking. Moreover, rational thinking has, in his opinion, its own categories: category of quantity, category of quality (internal certainty, orderliness, a set of properties of a specific phenomenon), category of relationship (independence and belonging, reason and action, interaction), category of modality (way of existence of a specific phenomenon) (Kalnoy, 2003).
A. Schopenhauer considered as the organ of intuitive cognition the intellect. According to him, the mind transforms intellectual cognition into abstract. The latter does not expand knowledge, but only gives it a new form, capable of performing practical functions and being an object of interpersonal communication (Toshchenko, 2011).

J. Piaget considered intuition as figurative objective thinking, characterizing mainly the prelogical stage of development (Posadova, 2014), believing, like K.G. Jung, that with the age, the role of intuition somewhat decreases and it gives way to a more social type of thinking - to a logical type. K.G. Jung called intuition that maternal soil from which grow thinking and feeling as rational functions (Jung, 1998). Thinking and intuition are two areas on the scale of awareness inherent to the inference process. Thus, intuition is assimilated to thinking - this is an unconscious inference, this is the process of generating decisions that flows unconsciously. A person may not realize some part of the process, or the whole process (Litvinova, 2002, p. 135-150).

Modern scientific paradigms define intuition as an extremely important moment in the complex and unconscious interaction of feelings, reason and experience. Sometimes it is interpreted as a certain focus of knowledge, which in its essence is not the initial stage of the latter, but a transitional link from one level to another. Under the influence of the ideas of existentialism (M. Heidegger, J. P. Sartre), intuition lost its epistemological characteristics and turned into a special way of human being in the world, which gives us the opportunity to consider it from the point of view of social philosophy.

The philosopher Mario Bunge (Bunge, 1967, p. 94), considers the most commonly used meanings of the term intuition, such as quick perception, imagination, abbreviated reasoning and sound judgment. M. Bunge distinguishes between sensual and intellectual intuitions. Sensual intuition, according to M. Bunge, has the following forms:

1. Intuition as perception. Intuition as perception is expressed in the process of rapid identification of an object, phenomenon or sign. Clear understanding of meaning and relationship or sign. The ability of interpretation.

2. Intuition as imagination. Ability to imagine or geometric intuition. The ability to form metaphors: the ability to show the partial 
identity of features or functions, or complete formal or structural identity in various objects. Creative imagination.

Bunge classifies intellectual intuition (intuition as mind) as follows:

1. Intuition as mind. Accelerated inference - a rapid transition from one statement to another, sometimes with quick omissions of individual links. The ability to synthesize or generalize perception. Common sense - is a judgment based on ordinary knowledge and not based on special knowledge or methods, or is limited by the passed stages of scientific knowledge.

2. Intuition as an estimation. Sound judgment, phronesis (practical wisdom), perspicacity or insight: the ability to quickly and correctly assess the importance and significance of the problem, the plausibility of the theory, the applicability and reliability of the method, and the usefulness of the action. Intellectual intuition as a common way of thinking (Bunge, 1967).

Having analyzed the existing conceptual approaches, we can note that currently there are several theories of intuition that explain its essence and content - as an epistemological, mystical, and as a primary superrational level of comprehension of "integral being", that involves the idea of mastering the world. That eventually acquires the look of a fairly clear guidelines of moral, political, scientific consciousness, providing a person with a certain direction of mastering the world, taking into account his needs and interests.

Thus, the common to all interpretations of intuition is the recognition of the immediate type of intuitive knowledge - it represents knowledge without awareness of the ways and conditions for acquiring. From this point of view, intuition is synonymous with perspicacity.

This peculiarity causes confusion among a number of scientists, who erroneously put the categories «intuition» and «perspicacity» in one row. Meanwhile, these concepts have different, albeit in some way similar semantic content.

The Philosophical Encyclopedia gives the following definition of perspicacity - direct guessing or understanding of one or another logical connection. It is crucial to distinguish perspicacity, understanding a priori from cognition a posteriori. Perspicacious person - is observant, prescient, noticing a lot (Isachenko,
2003). That is, we are talking about the human characteristic, his judgment abilities.

Intuition (Late Latin intuitio - contemplation, from in - in, inside; Lat. tui - be able, grow numb (become numb), you, to you; Lat. $t i$ (tum) - after, then, also from Lat. intueor - look fixedly) seems to be the ability to mentally assess the situation and, using the principle of idealization deduced by Galileo Galilei (a person can assert something without actual observing in reality), bypassing reasoning and logical analysis, instantly make the most correct decisions in a given situation.

From our point of view, intuition is the ability of a person and humanity to directly comprehend the truth based only on previous experience and without prior logical reasoning. Consequently, the category «intuition» is much larger than «perspicacity».

It is essential to understand that intuition is the most important unit of cognition in the system of relationships «I»- «YOU»- «WE». At the same time, the focus on understanding the other person is associated with empathy, as a sphere of interpersonal relations in the structure of emotional intelligence and as a personality trait, and allows to empathize with feelings that are identical to those observed, that is, it is irrationally to cognize the inner world of another person. Hence the possibility of interpreting intuition as a determinant of perspicacity, which is due to intuition as a method and ability to assess intelligence: the ability to quickly and correctly estimate the importance and significance of the information received, phronesis (practical wisdom) and sensory intuition as the ability to interpret.

In this context, for the cognition of a person's existence by an essential quality - existential, the independence of judgments is presented as a necessary component of perspicacity, directly related to the ability of making independent decisions and controlling oneself.

Research on perspicacity allows to consider it in two aspects: in the first, as the study of the social perception mechanisms, which anticipates the analysis of the interpersonal perception process and the study of various effects that accompany this process (stereotyping, halo, primacy, indulgence, novelty, and so on) (Andreeva, 2001; Kovalenko \& Kornev, 2006), in the second - as an analysis of a person's individual characteristics in the context of his perception, with the emphasis on the description of a person's emotional states, character traits, actions, etc. 


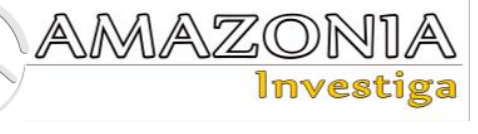

(Derevyanko, 2016; Gubsky, Korablev, \& Lutchenko, 2003).

From the point of view of psychology, O.P. Sannikova characterized perspicacity as a complex psychological formation, a personality trait that integrates and systematizes special knowledge and special personal qualities that allow an individual to accurately understand people, their incentive reasons for behavior, activities, and also to make perfect forecasts (Sannikova, 2009).

From the point of view of synergetics, the mechanism of intuition can be presented as a mechanism of self-organization, selfconstruction of visual and mental images, ideas, visions, thoughts.

However, when a person is under stress, in a state of anxiety and often uncertainty, his perspicacity is blocked and a person is not able to listen to his intuition. This precludes him to make adequate decisions in a crisis situation, which is now the COVID-19 pandemic.

\section{Results and discussion}

Some philosophers compare intuition with convictions or belief. For example, David Lewis (Lewis, 1983) writes: our «intuition» is simply opinions; our philosophical theories are the same. Some of them are common, and other are sophisticated; some are particular, and some are general; some hold on more firmly, some are less. But this all is just opinion. (Joel Pust 2017).

Such comments enable us to assume the following: obviously, there is a close connection between intuition and convictions, since a person usually believes the content of his intuition. If someone has found the way to a satisfactory resolution of the paradox and has identified a false judgment, it often happens that a person still has the intuitive sense that the rejected judgment is true. In this case, it is important to note a significant feature of intuition - its relative causal independence from explicit conviction. By analyzing the aforementioned, we can conclude that intuition is convictions with a suitable etiology.

V. F. Reyna (Reyna, 2021) studied the interconnections between analytical thinking, false convictions and observance of various COVID-19 recommendations at different times during the pandemic and in several different countries. According to her research, people with false convictions about the COVID-19 pandemic were less likely to follow COVID-19 recommendations. Researches have emphasized that dispositional analytical thinking is a strong and consistent means of predicting false convictions, conspiratorial beliefs and misconceptions about COVID-19. The connection between analytical thinking, intentions and behavior is less visible. While analytical thinking comprehensively cannot predict the correctness of the required behavioral acts or intentions to change people behavior during a pandemic. The findings of her research correspond to the model according to which people unwilling to participate in these thinking and reflexive cognitive processes are less likely to demonstrate socially correct behavior because they considered a pandemic as a hoax. Since this study had been carried out on March 21, 2020, many US states introduced mandatory social distancing measures. However, the public opinions on the value and necessity of these measures were divided (Reyna, 2021).

Intuition in social perspicacity is based on rational thinking («intellectual intuition»). Therefore, insight does not come accidentally, but as a reality comprehended in a special way, understanding of a huge amount of information and the formation of one's own judgments due to the inclusion of analytical thinking processes. At the same time, it is crucial to take into account individual psychological characteristics of a person. Individuals who are more prone to panic, hysteria and cyclicity while constantly monitoring the negative information in the social media about a pandemic will intuitively block useful information about precautionary measures. And in these conditions, intuition can acquire the stability of prejudice or delusion if, being effective in relation to one social process, it becomes unquestioningly transferred to other social processes and phenomena - forming not intuitive connections, but false unconscious attitudes, in relation to one or another phenomena. At the same time, it should be noted that the positive reinforcement of false ideas will play a negative role and reduce people's confidence to their intuition, which directs the instinct of self-preservation that contributes to the acceptance of restrictions imposed by the pandemic in social interaction and will in no way contribute to its stalling and control.

Intuition can turn into daydreaming if it does not rely on a significant information base. In this case, it becomes akin to quackery, which operates with random, little related one to another clues, and relies on speculations and arbitrary interpretation of the events that came to 
hand (Toshchenko, 2011). And often such a process is triggered while receiving false information from the media, and this process affects the people's behavior associated with panic during the COVID-19 pandemic. The deliberate exaggeration of the situation about the pandemic in the media only disorients people and forms fears, phobias, aggravates stress and neuroses, which, in turn, deactivate the natural intuitive processes aimed at self-preservation. In this context, it is important to understand the role and significance of innate ideas that are inherent in thinking initially and are not acquired from experience and cannot be changed on the basis of experimental knowledge. Usually these are ready-made ideas or concepts on which people rely as true, or ideas inherent in thinking as potential abilities and inclinations. The key importance is that these possibilities should be realized, seen and supported, and also used when deciding the future of one or another process or phenomenon. The imposition and blocking of social contacts for people as for social beings, causes internal resistance and triggers psychological defense mechanisms to block this information. Since this contradicts the natural way to which a person is accustomed, most states cannot achieve the compliance with quarantine measures and social distancing. Being in isolation with a constant information flow about the deterioration of the epidemiological situation, without knowing when this situation gets resolved, in the absence of ready-made algorithms for solving this problem, a person finds himself in a state of frustration, which forces him to combat and resist the imposed rules and regulations. Therefore, there are a lot of violations in different countries: protests, riots, strikes, etc.

Of course, there is no state that in the current situation can afford to abandon restrictions under the increased COVID-19 incidence. But the approach to providing the information necessary for saving lives should be changed. Based on the study of the intuitive behavior formation mechanisms, it is important to pave the way for the formation of an unconscious assimilation of the experiencing difficult situations not in cohesion with a group, but individually, basing on the use of obedience to authority in difficult situations. Providing clear instructions and creating new response algorithms will help to form correct knowledge about behavior in a pandemic situation. Due to the constant mutation of the virus, humanity for some more time will have to live in conditions of limited social interaction. The importance of unconditional acceptance of certain restrictions in social life is quite acute today, therefore, the study of the intuitive processes of the behavioral acts formation is gaining relevance.

\section{Conclusions}

It is important to support public opinion, and this process will take years and for that reason should be started now. Leaders must make a concerted effort to explain why this research is saving lives. And, more broadly, they must explain the importance of science in coping with the pandemic impact.

Intuition exists and plays a significant role in cognition. The process of scientific and, moreover, artistic creativity and comprehension of the world is no means always carried out in an expanded form divided into stages. Quite often, a person covers a difficult situation with his thoughts, without going into all its details, and simply not paying attention to them. This is especially evident in military battles or when making a diagnosis. Intuition is essential in moral life, in historical and humanitarian knowledge in general.

It should be noted that the effectiveness of the solution is enhanced by special motivation. Moreover, in the situation when ineffective methods of solving the problem are exhausted and the search dominant has not yet faded away - the less automated the method of action, the more chances to solve the problem. The specialist's intuition usually surpasses the amateur's intuition.

Therefore, the point of view that intuition is regarded as evidence in philosophy will be best considered as the view that, with respect to many fundamental questions of philosophy, our justification of belief lies in the fact (at least essentially) that we have the appropriate intuition. It does not mean that all explicit philosophical reasoning can be correctly presented as starting with statements that assert that we have intuitions of various kinds.

\section{Bibliographic references}

Andreeva, G.M. (2001) Social Psychology. Text book for higher educational institutions. Moscow: Aspect Press, p. 290 URL: http://umo.edu.ua/images/content/aspirantur a/zabezp_discipl/1358737958_andreeva_soc ialnaya_psihologiya.pdf (in Russian)

Balabantaray, S. R, \& Mohapatra, A. (2020). Combating the Coronavirus disease 2019 pandemic: 'Lockdowns' amplify the problem. 


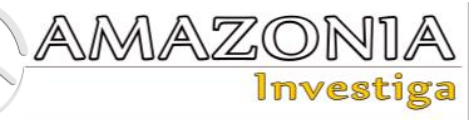

Journal Medical Evidence, 1(1), 51-53. URL: http://www.journaljme.org/text.asp?2020/1/ 1/51/290149 (in English)

Bunge, M.A. (1967). Intuition and Science. Moscow: PROGRESS, p. 188 URL: https://platona.net/load/knigi_po_filosofii/fil osofija_nauki_tekhniki/bunge_mario_intuici ja_i_nauka/30-1-0-1077 (in Russian)

Derevyanko S.P. (2016) Phenomenology of emotional intelligence: a textbook. Chernihiv: "Lozovy VM" URL: erpub.chnpu.edu.ua:8080/jspui/handle/1234 $56789 / 640$ (in Ukrainian)

Gubsky, E.F., Korablev, G.F., \& Lutchenko, V.A. (2003). Philosophical Encyclopedic Dictionary. Moscow: INFRA-M, p. 576 URL: http://www.rubricon.com/fes_1.asp (in Russian)

Ilyichev, L.F., Fedoseev, P.N., Kovalev, S.M., \& Panov, V.G. (Ed.). (1983). Philosophical Encyclopedic Dictionary. Moscow: Soviet Encyclopedia, p. 840 URL: https://platona.net/load/knigi_po_filosofii/sl ovari_ehnciklopedii/filosofskij_ehnciklopedi cheskij_slovar_1983/23-1-0-1634 (in Russian)

Isachenko A. V. (2003). "The grammatical structure of the Russian language in comparison with Slovak. Morphology. Part 1, 2". Publisher: "Languages of Slavic Culture" 880 p. URL: http://www.bibliorossica.com/book.html?cur rBookId=3785 (in Russian)

Joel Pust (Ed.). (2017) Intuition. Stanford Encyclopedia of Philosophy. First published Tue Dec 4, 2012; substantive revision Tue May $9, \quad 2017 \quad$ URL: https://seop.illc.uva.nl/entries/intuition/\#pag etopright (in English)

Jung, K. (1998). Psychological types. Moscow: University Book, AST URL: http://publ.lib.ru/ARCHIVES/YU/YUNG_K arl_Gustav/_Yung_K.G..html\#0001 (in Russian)

Kalnoy, I.I. (Ed.). (2003). Philosophy for graduate students. St. Petersburg: Lan, p.513 URL:

https://obuchalka.org/20100323281/filosofiy a-dlya-aspirantov-uchebnik-kalnoi-i-isandulov-u-a-2003.html (in Russian)

Kant, I. (1994). Criticism of Pure Reason. Moscow: Thought. URL: https://platona.net/load/knigi_po_filosofii/ist orija_nemeckaja_klassicheskaja/kant_kritika _chistogo_razuma/12-1-0-563 (in Russian)

Kovalenko A.B., \& Kornev M.N. (2006) Social psychology. Pidruchnik. 2nd type. Kiev: Geoprint, $\quad 400 \quad$ s. $\quad$ URL: https://www.twirpx.com/file/3104405/ (in Ukrainian)

Kravchenko, S. A. (2002). Sociology. Moscow: PERSE; Logos, p. 640 URL: https://sociology.knu.ua/sites/default/files/lib rary/elopen/kravchenko.pdf (in Russian)

Lewis, D. (1983). Truth in Fiction. American Philosophical Quarterly, 15(1), 37-46. Philosophical Papers: Volume I, New York: Oxford University Press. DOI: 10.1093/0195032047.001.0001

Leshchyna, I.V., Asieieva, Yu. O., Vasylieva, O.V., Strelnikova, I.M., \& Kovalska, N.A. (2021). Adjustment disorders in international students studying in English during a pandemic. Amazonia Investiga, 10(48), 200-208. DOI: https://doi.org/10.34069/AI/2021.48.12.21

Lindhard, T. (2020). Intuition: A Heart-based Epistemology. Dialogo, 7(1), 181-194. URL: https://www.ceeol.com/search/articledetail?id=918273 (in English)

Litvinova, A. L. (2002). The role of intuition in scientific knowledge. Philosophy about the subject and subject of scientific knowledge (p. 135-150). St. Petersburg: St. Petersburg Philosophical Society. URL: http://anthropology.ru/ru/text/litvinovaal/rol-intuicii-v-nauchnom-poznanii (in Russian)

Nakonechnaya, N. (2016). What is discernment? Video. Youtube. URL: https://www.youtube.com/watch?v=ateC721 2TSY

Newton, I. (1989). Mathematical principles of natural philosophy. Moscow: Science, Editorial of the USSR Academy of Sciences, p. 688, URL: https://platona.net/load/knigi_po_filosofii/ist orija_novoe_vremja/njuton_isaak_matemati cheskie_nachala_naturalnoj_filosofii/10-1-0127 (in Russian)

Posadova, L.A. (2014). The role of intuition in the knowledge of the world. Existed. URL: (in Russian) https://existed.ru/intuiciya-vprocesse-poznaniya-intuiciya-i-e-rol-vpoznanii-ponyatieintuicii-v/

Reyna, F. V. (2021). A scientific theory of gist communication and misinformation resistance, with implications for health, education, and policy. PNAS, 118(15), 1-6. URL: https://www.pnas.org/content/118/15/e1912 441117/tab-article-info (in English)

Sannikova, O. P. (2009). On the structure of psychological insight. Methodology and technologies of practical psychology in the system of higher education: Abstracts of reports of the participants of the Second 
International Conference. Kyiv: MP Drahomanov National Pedagogical University of the Ministry of Education and Science of Ukraine, Polygraph Center. URL: https://spbappo.ru/wpcontent/uploads/2020/09/2014.pdf

(in Russian)

Siddharth, S. (2020). The Pandenomics of COVID-19: Behavioural Insights. University news, 58(18), 17-21. URL: https://www.researchgate.net/publication/34 2673051_The_Pandenomics_of_Covid19_Behavioural_Insights (in English)

Toshchenko, Zh. T. (2011). Sociology of management. M.: Social Welfare and Marketing Center. URL: (in Russian) https://www.isras.ru/publ.html?id=2175 